\title{
COVID-19 and Quarantine: The Role and Impact of Media in Kosovo's Society
}

\author{
Ferdi Kamberi ${ }^{1}$, Besim Gollopeni ${ }^{2}$
}

\author{
${ }^{1}$ University of Prishtina \\ Rr. "George Bush", p. n., 10000 Prishtinë, Republika e Kosovës \\ 2 University of Mitrovica "Isa Boletini" \\ Street Ukshin Kovacica, 40000 Mitrovica, Republic of Kosovo
}

DOI: $10.22178 /$ pos.64-4

LCC Subject Category:

HN50-995

Received 16.09.2020

Accepted 28.10.2020

Published online 30.11 .2020

Corresponding Author:

Besim Gollopeni

besim.gollopeni@gmail.com

(C) 2020 The Authors. This

article is licensed under a

Creative Commons

Attribution 4.0 License

(c) (1)

\begin{abstract}
The outbreak of COVID-19 and the quarantine affected Kosovo society by highlighting the media's role and importance in informing and raising citizen's citizens in a pandemic situation. At a time like this, besides the information and citizen's awareness, this situation was accompanied by a lot of fake news, complicating the social and psychological problems of the audience/citizens, leading to fear, anxiety, and social insecurity. Many media were driven by the desire of material interests, especially the online portals, social networks, etc., offering fake or false news to the public for the sole purpose of their material gain. This study aims to research the Kosovar media's role and impact during the pandemic and quarantine time. For this research, we have used the online questionnaire (Google Form) during July and August 2020. The target group was the population over $15(\mathrm{~N}=908)$ in Kosovo's entire territory. T-test, analysis of variance (ANOVA), and other methods were used to analyze the data. The study results show that $51 \%$ of Kosovar citizens informed about COVID-19 during the pandemic and quarantine had used social networks. More than $63.7 \%$ of citizens were heavily influenced and, on average, by fake news. Fake news and misinformation from the media in Kosovo society hurt specific society categories, especially those with lower levels of education and social and economic problems, causing fear, social anxiety, and social insecurity.
\end{abstract}

Keywords: media; role; impact; Kosovo; COVID 19; quarantine.

\section{INTRODUCTION}

The COVID-19 outbreak affects all segments of societies. It is particularly detrimental to members of those social groups in the most vulnerable situations, continues to affect institutions, including people living in poverty situations. In this situation, the role and impact of the media are at their peak. The media is considered to be the primary agent of socialization after family and school. The development of the media took place after the Second World War, especially with science, technology, and informatics. Today it is difficult to imagine life without media because of the role and influence they have in society on the one hand and the impact on social changes on the other hand. The media is considered a product of globalization. The manifestation of 'fake news' has caused the media through social networks and mostly fictitious portals to increase social anxiety and social insecurity and increase populism worldwide, thus threatening the democratic system. Many countries (Singapore, Russia, European countries), realizing the media's influence, have passed laws against fake news. With the outbreak of COVID19 , "misinformation in the public domain becomes an infodemic, i.e., a pandemic of incorrect information, posing great risks to global health. Misinformation, disinformation, and conspiracy theory claim that Coronavirus is a bio-weapon, a spy operation, a medico-business strategy, a population scheme, or a religious mission" [6]. Disinformation led to social disharmony, even inconsistencies with public health measures, the experience of political and social conflicts, discrimination, adverse psychological and social effects. This situation becomes even more difficult in times of pandemics.

As the number of COVID-19 cases increased, the public interest in the media to learn more about COVID-19 increased. The new COVID-19 seemed 
very contagious and has quickly spread globally. As of April 03, 2020, there has been a minimum of 52,869 deaths, and quite 10.10 .066 confirmed cases of this coronavirus pandemic. On September 13, 2020, demonstrated cases increased to 28 637952 with deaths of 917417 in 2016 countries" [23]. The COVID-19 situation and quarantine have further increased media-society interaction, leading the latter to a dependence on the media and especially on social media to obtain information about COVID-19. However, in such a situation, where fear, panic, and social anxiety are high and in such less emancipated, educated societies, fake news's effects come to the force more than anywhere else. In Kosovo, as in many other countries, the media "have played an important role in informing and raising public awareness regarding the global COVID-19 pandemic, safeguards, physical distance and everything else regarding COVID-19, but at the same time during this time, false news appeared which consequently led to fear, panic, anxiety and social insecurity and this whole situation have led to an increase in domestic violence in Kosovo". Such media built many conspiracies, which consequently had the citizen's distrust in the existence of COVID-19, making it even more difficult for institutions to deal with COVID-19. The aims of this study were (a) the most frequented media in the time of COVID-19 and quarantine, (b) the influence of citizens from the fake news regarding COVID-19, and (c) the media and public awareness regarding COVID-19- 19 and the interrelationship of several variables to impacts.

\section{Literature review}

The 21st century is considered to be the era of globalization and post-modernity, a century in which man, as a social-biological being, has almost reached the highest pedestals in its development. Undoubtedly, the development of science and technology has given its results, especially the invention of the 'magic wand' has made the world communicate from one end to the other. For sociologists, the media are socialization agencies that have, among other things, the educational role of citizens. On the other hand, they can have negative impacts that can produce deconstructive situations and cause a breach society's balance. According to Francis Bacon, the media is considered the fourth power; after the legislative, executive, and judicial branches. Whereas, according to Noam Chomsky, there are two theories, "which support the media's fundamental role. He considers the first role based on the traditional (Jefferson) model, which implies the media apparatus as a balance of power apparatus. According to this model, the media in its contents creates a balance not only informative but also cultural. The second role of the media is based on the propaganda model, with which the government and the journalist are seen as 'servants and supporters of the power structures" [3]. Louis Althusser has grouped the media with the family, the church, and the education system under the heading of 'ideological state apparatuses' [2]. Today, several theories talk about their relationship with society. Another view commonly used by the media is symbolic interaction, which asserts "that the self is derived from and develops through human interaction. This means the way you act toward someone or something is based on its meaning for a person or thing. To communicate effectively, people use symbols with shared cultural meanings. Symbols can be constructed from just about anything, including material goods, education, or even how people talk. Consequentially, these symbols are instrumental in the development of the self" [15]. This concludes that media power is high enough to create symbols in itself, which was evident in COVID-19 and quarantine. With this theory's help, researchers can look at how the media influences society's familiar characters and, in turn, the impact of these symbols on society. While, according to media dependency theory, "during a severe social disruption, there is an unusually high need for information and sense-making by individuals and the mass media are generally perceived to satisfy these needs best. Specifically, the public relied heavily on the media to obtain information regarding operationalized guidance to the public, the response of organizations, and exchanging views with others. One of the reasons people usually need more information in crisis events is to reduce the anxiety caused by uncertainty in the crisis event. Research showed that uncertainty and uncontrollable feelings in the H1N1 epidemic were positively related to stress and anxiety. Therefore, people actively engage in information-seeking from a variety of sources to reduce uncertainty in a crisis event to ease their anxious feelings" [14]. As well, "many studies have found that media exposure during critical public events may further cause psychological trauma and anxiety, indicating that the media's vicarious traumatization effect may play an important role. After the 9/11 attack, people exposed to more 
television images of people falling or jumping to their death reported a higher posttraumatic stress disorder (PTSD). Thompson and colleagues also argued that media exposure to mass violent events could fuel a cycle of distress" [14]. Such a situation has occurred with the global COVID-19 pandemic and quarantine situation. In Kosovo's case, interest in the media during the pandemic increased, and "Numerous and different disinformation has been spread since the Coronavirus was first reported, mainly on social media. In Kosovo, social media such as Facebook is one of the main sources of information and, at the same time as a source of disinformation. Citizens have been exposed to a wealth of misinformation that has above all caused panic among citizens and, as a result of citizens' tendency to disseminate any information they read, unverified and often false, they have penetrated an even wider public" [7].

\section{METHODS}

In the study participated a total of 908 respondents ( $\mathrm{N}=908)$. The study was conducted from July to August 2020 (July 27 - August 23, 2020). The participants in the survey are resident citizens of Kosovo, adults (over 15 years old). Among them, about $68 \%$ of women and $32 \%$ were men. Regarding the age-groups involved in the study, it varies from 15 to 79 years old. Age-group 15 - 20 years is represented by $7 \%$ of respondents, 21 30 years is represented by $34 \%, 31-40$ years is represented by $36 \%, 41-50 \%$ is represented by $16 \%$, the group - age $51-60$ years is represented by $5 \%$ and the age group over 61 is represented by $2 \%$ of the total number of respondents. The respondents' average age (male and female) was 39 years $(\mathrm{SD}=8.9)$. The respondents' education level was: with primary education $1.1 \%$, secondary education 18.2\%, and higher education (bachelor, master, and Ph.D.) 80.7\%, with an average of 15.1 (SD = 3.3). $30 \%$ from rural areas and $70 \%$ of urban regions participated in the study. Of the respondents, $60 \%$ lived at home while, $40 \%$ lived in the apartment. Of the total number of respondents included in the survey, $12 \%$ were infected with COVID-19. Before starting to complete the questionnaire, respondents had information and instructions for completing the instrument.

Table 1 - Descriptive analysis of study respondents

\begin{tabular}{|l|l|}
\hline $\begin{array}{c}\text { Number of } \\
\text { respondents, } \\
\text { total - 908 }\end{array}$ & \multicolumn{1}{|c|}{$\%$} \\
\hline Gender & $\begin{array}{l}\text { Male 32 } \\
\text { Female 68 }\end{array}$ \\
\hline Age group & $15-20,7$ \\
& $21-30,34$ \\
& $31-40,36$ \\
& $41-50,16$ \\
& $51-60,5$ \\
& Over 61, 2 \\
\hline Education level & Primary school 1.1 \\
& Secondary school 18.2 \\
& University studies (Bch., \\
& MSc. Ph.D.) 13 \\
\hline Rural-Urban & Rural 30 \\
& Urban 70 \\
\hline Residential & Home 60 \\
& Flat 40 \\
\hline
\end{tabular}

The study was comprehensive and with a representative sample. Based on the sample number $(\mathrm{N}=908)$, the inclusion, and the representative sample, we can conclude.

The authors designed the instrument, and was implemented online (Google Form), distributed to the respondents electronically via the Internet and social media. The questionnaire consists of three sections. At the beginning, where the demographic and social questions; how much do the citizens know about global endemics and pandemics (COVID-19) and civic trust in the media in Kosovo. The last section was questioned about media attendance, media and awareness, and the impact of fake news. Participants were asked to rate each question on a Likert scale: (4) a lot, (3) average, (2) a little, and (1) not at all. The questionnaire was standardized and enabled conclusions drawn regarding the media's role and influence in pandemic times. The statistical package used in this study was SPSS Version 20.0.

\section{RESULTS AND DISCUSSION}

Since the appearance of COVID-19 in Wuhan, the capital of Hubei province in China, in December 2019, the media all around the world reported on a new, invisible, and unknown enemy. In addition to this situation, we were exposed to false news and disinformation, spread mainly through social media (social networks), which have become a global trend. The International Telecommunication Union's latest report revealed that $53.6 \%$ of 
the worldwide population, or 4.1 billion people, uses the Internet till the end of 2019" [9].

This implies that all are using the Internet. In fact, "according to a survey, there is $87 \%$ of the increase in social media usage during lockdown" [18] worldwide. Therefore, the media are the primary source of public information during the global pandemic. However, there was also 'fake news,' which negatively affected society worldwide, spreading fear and panic among the citizens. This spread of terror and misinformation about COVID-19 is otherwise known as 'Misinfodemics'. According to the UNESCO report on 'Journalism, Freedom of the Press and COVID-19', in terms of timely information and misinformation of the pandemic, such as:

a) Based on a machine learning analysis of 112 million public social media posts, in 64 languages, related to the COVID-19 pandemic, researchers at the Bruno Kessler Foundation found $40 \%$ of posts came from unreliable sources,

b) Another study using machine learning techniques, by the Foundation's COVID-19 Infodemic Observatory, found that bots produced almost $42 \%$ of over 178 million tweets related to COVID19 , and $40 \%$ were "unreliable",

c) Roughly $1 / 3$ of social media users have reported seeing false or misleading information about the Coronavirus, says a study by the Reuters Institute in six countries. Research by Pew suggests that people who receive their news primarily through social media are more likely to be exposed to false content,

d) In March, about 40 million problematic posts related to COVID-19 on Facebook were identified (and had warnings placed next to them), according to the company. "Hundreds of thousands of pieces of misinformation about the virus that could lead to imminent physical harm" were also removed, it added,

e) Approximately 19 million out of nearly 50 million (38\%) tweets related to COVD-19 analyzed using artificial intelligence by Blackbird.AI were deemed to be "manipulated content",

f) Newsguard identified 191 websites in Europe and North America that have published false information about the virus,

g) The Coronavirus Facts Alliance has discovered - and disproved - more than 3,500 false or misleading pieces of information, in more than 70 countries and more than 40 languages" [21].
During the quarantine period, the only source of information for the citizens was the media. According to these data, part of the story was not knowledge but disinformation, which caused psychological and social confusion. The Coronavirus outbreak has also produced several conspiracy theories, which have been readily accepted by various social groups. The invention of the vaccine by the Bill Gates Foundation, the origin of COVID19 as a product from China, and the placement of $5 \mathrm{G}$ antennas are just some of the conspiracies that have circulated the world. Even "in Britain, dozens of $5 \mathrm{G}$ mobile phone towers have been set on fire; police say many of the attacks were motivated by a false belief that this technology is linked to the coronavirus pandemic.

Several studies conducted by (Kings) College in London and the survey company IPSOS MORI, show a strong link between the belief in such conspiracy theories and reliance on social media as a source of information, including Facebook, YouTube, Twitter, and WhatsApp. These groups of people prefer to avoid television or print media. Among those who believe that the Coronavirus does not exist at all, about $56 \%$ cited Facebook as their primary source of news - information. "Facebook, Twitter, and YouTube say they have removed hundreds of thousands of videos and posts containing disinformation about COVID-19 with immediate harmful consequences" [22].

Such conspiracies have been circulating almost all the time in Kosovo, taking into account the fact of high use of the Internet by Kosovars where, "in 2017 the percentage of households that had Internet access was $88.8 \%$ while in 2018 it increased by $4.4 \%$ compared to 2017 wherein 2018 it reached $93.2 \%$ while in 2019 no changes were observed in the percentage of households accessing the Internet at home, from any device, while in households that did not have Internet access in houses, from any equipment, compared to 2018 there was a decrease of $0.55 \% "$ " [1].

In Kosovo's context, during the last decade, they have made a 'revolution' in themselves, especially after the Internet's massification, which has already become a need not only of the media but also the general public. This is due to its use by the new generations, which in sociological language are also known as the "generation of globalization" [11]. This massification of information technology has made the media, primarily through virtual platforms, increase. According to the Independent Media Commission, in 2018, Kosovo has 
20 television stations, 83 radio stations, 61 program service providers, and 38 distribution operators. There are five daily newspapers in Kosovo, while the number of online media remains unknown" [4]; these media are increasing day by day. But what were the most frequented media by the citizens during the quarantine?! From the findings of the study, we understand that the most frequented media for March to August 2020 by Kosovars are: social networks (51\%), television $(33.3 \%)$, portals $(14.1 \%)$, press $(1.5 \%)$, and radio $(0.1 \%)$

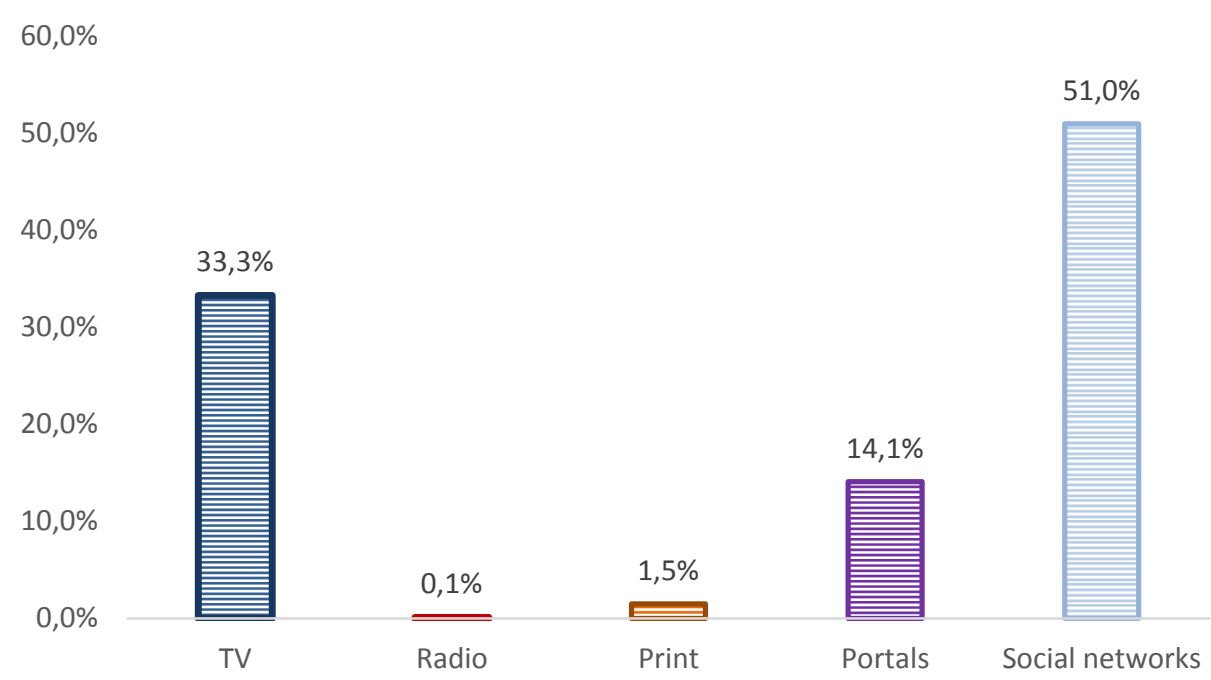

Figure 1 - Attendance/frequent of media during the pandemic COVID-19

The fact that social networks are more frequented and unconfirmed data or information is placed in them makes the situation more difficult to manage and creates confusion and insecurity among people. During the period between March and August 2020, according to the site 'Google Trends', Kosovars have requested the most information for three keywords, such as Coronavirus, COVID-19 and Virus, while, according to cities such as: "in the city of Gjakova the word the most requested key is (86\%) coronavirus, COVID-19 (10\%) and Virus (4\%), in the city of Peja with $82 \%$ was the word coronavirus, 15\% COVID-19 and Virus 3\%, in Prizren $81 \%$ the word coronavirus, $15 \%$ COVID-19 and 4\% Virus, as well as in Prishtina 80\% coronavirus, 17\% COVID-19 and Virus 3" (Google-Trends, 2020). This shows that citizens during Covid-19 and quarantine were very active in seeking information in the media about the situation of COVID-19. "The interest of citizens in scientific research on the words virus, COVID-19 and coronavirus come as a result of the lack of information on global epidemics and pandemics (COVID-19) by citizens and for $61.2 \%$ of citizens (N=908) had believed" Few "or" did not "believe that such a pandemic (COVID-19) could occur in Kosovo.

\section{Citizen awareness and fake news in Kosovo}

The COVID-19 has continuously been reported in the media. In this regard, the media have played an essential role in informing the situation, keeping the public updated, but there has been a massive presence of fake news during this time. Since the pandemic outbreak, over 1500 phoney information has been distributed all over Kosovo [13], and this number may already be much higher in reality. Some of the headlines that have been reported by social media or in portals are:

"The Coronavirus is an alternative biological weapon deployed by China, the US, the United Kingdom or even Russia (to destroy the EU and NATO), the Coronavirus did not explode in Wuhan, China the US is hiding its true origin, which is American laboratories or US property worldwide. Migrants cause the spread and migrants landing in the EU, Coronavirus is linked to $5 G$ (e.g., Wuhan as a $5 G$ testing ground), EU has failed to address the crisis the EU is a disaster for Europe, The EU is not ready to provide urgent support to Member States - on the contrary, they should rely on external support (example Italy), with China most often cited as the source of such assistance, China is coming to save $E U$ as Brussels abandons EU member states, Schengen no longer exists - Europeans are quarantined. Still, migrants can move freely; Coronavirus 
is a joke, it does not exist, the EU can impose mass vaccinations, Kura: claims that natural remedies exist to cure the virus, which is often combined with anti-vaccine stories, Various conspiracy theories: historical predictions about the pandemic, the plagues that hit the planet, the secret "Deep State" efforts to control population growth, the pandemic caused by chemical weapons or leading to World War III" [12].

Fake news has created confusion among people and increased their distrust in the public and government institutions. We found a significant corelation between fake news and social insecurity $(\mathrm{N}=908)=.001$ for both groups (male and female). Often fake news is used as a means for material gain. Even though there is a legal framework in Kosovo that regulates such an issue, however, during the pandemic, there is no report on the single case when someone was interrogated, investigated, or arrested for any fake news. Realizing the consequences of fake news in our society, a group of young people in Pristina has recently created a platform, "No Fake News," which aims to combat false (fake) and no real news. To understand how much the fake news during the pandemic (quarantine) has affected the Kosovar society, the study focuses on the respondents' direct question: How much did the fake news from the media influenced during the pandemic time? We found that fake news and the media, in general, have had a high impact on citizen's lives.

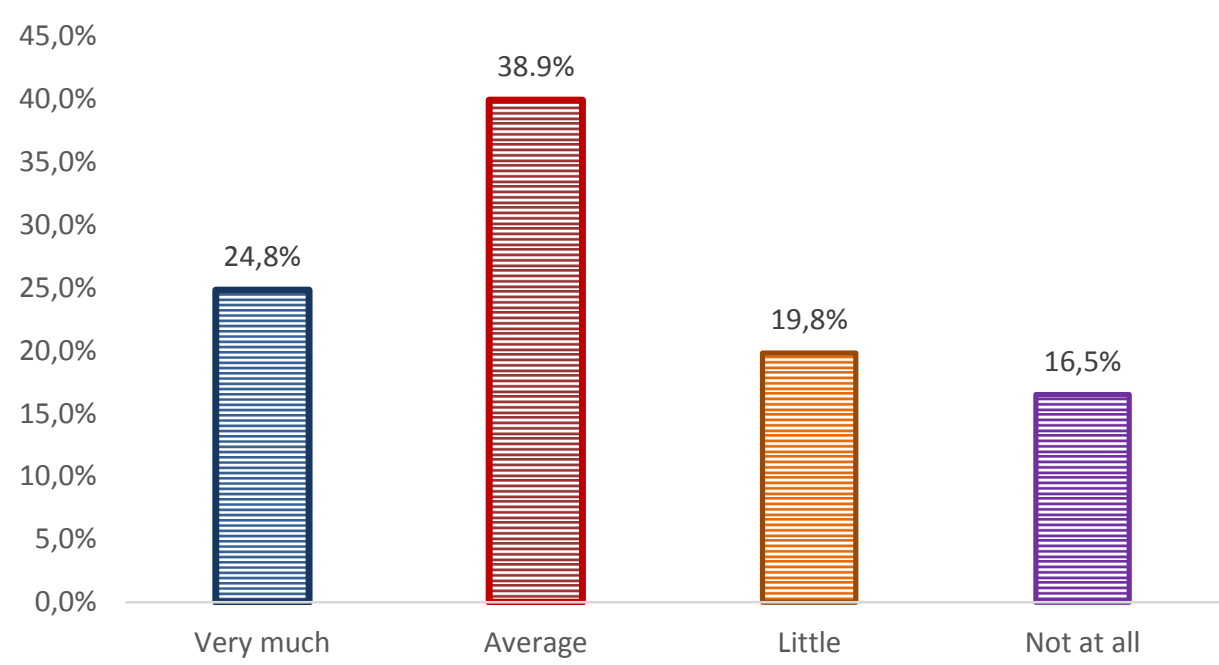

Figure 2 - Impact of fake news on the citizens

The results show that $24.8 \%$ of citizens were affected by fake news, $38.9 \%$ were moderately affected, $19.8 \%$ were slightly affected, and $16.5 \%$ were not affected. Overall, more than two-thirds of citizens are affected by fake news in pandemic times. Fake news mostly affects citizens with a low education level (91\% primary school) and high school (67\%). There is a significant relationship p $(\mathrm{N}=908)=.0001$ between the low level of education of the citizens involved in the study and the impact of fake news. As we mentioned above, the media plays a vital role in raising public awareness. Social isolation during the COVID-19 pandemic (quarantine) for $75.1 \%$ of respondents was "very" and "moderately" stressful. In such a situation, the media plays an essential role in overcoming this situation and raising public awareness of COVID-19. Our findings show that in $43.3 \%$ of citizens, the media had a massive impact on cognition. In $39.9 \%$ of citizens, the media had a moderate effect. For $9.5 \%$ of citizens, the impact of the media on awareness of COVID-19 was small.

Whereas, about 7.3\% of the citizens in Kosovo, the media in pandemic times did not positively affect awareness of COVID-19. Based on our study's findings, we understand that the media have an essential role in raising citizens' attention to face social and other causes, such as COVID-19. 


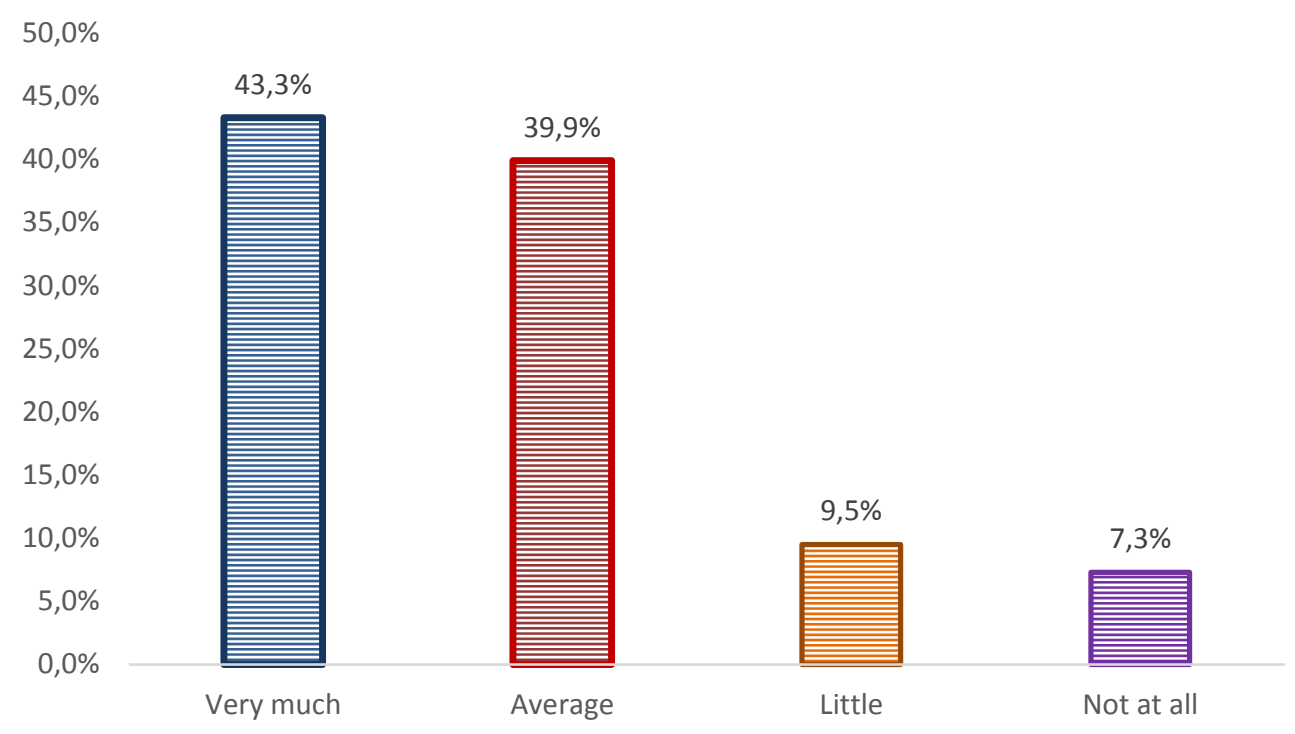

Figure 3 - The impact of the media on citizens' awareness of COVID 19

\section{Psychological and social effects of fake news}

We are witnesses of "the growing popularity of digital information platforms and the sharp decline in newspaper circulation, and network news ratings have led many scholars to speculate that new media would eventually replace traditional sources of news and information" [9]. In this regard, the role of the media in society is enormous. On the one hand, they inform the public and are the first channels of information. On the other hand, through reporting, the media can reveal irreparable consequences for society and specific social categories. In the case of the global pandemic, as a result of media reports, contemporary society is even more immersed in psychological confusion. The studies show that "within days of onset of the COVID-19 outbreak in China, the 'social media panic' characterized by a relentless plethora of fake information as well as negatively skewed misinformation metastasized faster than the Coronavirus itself. The director-general of WHO has referred to this to "coronavirus infodemic" which is breeding fright and panic by laying out rampant mind-boggling rumours, flamboyant news propaganda, and sensationalism" [5]. Such news has caused many confusions in society, caused stress, social anxiety, and social insecurity, and this led to the depression. In fact, this "these invite several overwhelming mental burdens in the form of anxiety, phobia, panic spells, depression, obsession, irritability, delusions of having symptoms similar to COVID-19 and other paranoid ideas. Healthcare seekers are too much perplexed, catastrophized, and morbidly worried about COVID-19 symptoms that the normal running of healthcare systems may get disrupted to address the mass anxiety owing to massive disinformation" [19]. The pandemic situation of COVID-19 for the citizens of Kosovo has caused fear $(60.9 \%)$, panic $(45.7 \%)$, anxiety (34.8\%), and social insecurity (76.3\%). This situation has had negative consequences, among them have caused panic and insecurity among citizens. For example, US citizens have had a problem with toilet paper because there was a lack of them; in the Netherlands, this is manifested by the lack of marijuana. In this country, marijuana is legal.

In contrast, in the Western Balkans, including Kosovo, this form of panic is manifested by a lack of essential foods. Other consequences that this misinformation has caused are the use of various medications to reflect on people's mental health, even leading to suicide due to lack of social stability. Do other studies talk about why infodemics can make the pandemic worse? Listing some reasons, such as

a) makes it hard for people, decision-makers, and health workers to find trustworthy sources and reliable guidance when they need it. Seeds may be apps, scientific organizations, websites, blogs, "influencers," and more,

b) People may feel anxiety, depression, overwhelmed, emotionally drained, and unable to meet essential demands,

c) It can affect decision-making processes when immediate answers are expected and not enough time is allotted to analyze the evidence deeply, 
d) No quality control on what's published, and sometimes, on what's used to take action and make decisions,

e) Anybody can write or publish anything on the web (podcasts, articles, etc.), in particular on social media channels (individual and institutional accounts)" [17].

There is also a connection with the theory of Dyrkem, who claims that social connection is a critical factor in emotional health and social stability, which shows a correlation between misinformation, social strength, and social relationships. Therefore, it is evident that misinformation has caused various phobias, anxiety, depression, psychosis, and neurosis in psychological terms. In the social aspect, they have raised the great fear in the society of what the future will produce.

\section{CONCLUSION}

Based on the findings, analysis, and comparison of data taken from this survey, we conclude that the media had a huge impact and role in informing and raising awareness of citizens in the global pandemic situation (COVID-19). The media had an enormous impact on informing the citizens about the extent of the Coronavirus spread. The relevant institutions take the steps and measures to prevent the further spread of COVID-19, the quarantine situation, and all other issues related to the COVID-19 pandemic. False news hurts society, especially on different categories of society. A lower level of education, young age group, and the elderly have caused psychological confusion and produces fear, social anxiety, panic, and social insecurity. Fake news (38.9\%) and misinformation have affected the health of citizens. Fake news has also hurt public awareness. The most common false information comes in the form of conspiracy theories such as COVID-19 does not exist, it has interconnection with $5 \mathrm{G}$ antennas, this is a war of great powers (US, Russia, China), and the great forces invented the Coronavirus. Fake news is a challenge for Kosovar society and severe media in the country. As in many countries worldwide, in Kosovo, the media, in most cases, through misinformation, have produced adverse effects because people tend to believe and share information, especially when the pressure on them is high. Therefore, these effects have also influenced the increase in domestic violence in Kosovo.

\section{REFERENCES}

1. ASK. (2020). Rezultatet e Anketës së Përdorimit të Teknologjisë Informative dhe Komunikimit 2019. Retrieved from https://ask.rks-gov.net/media/5270/tik-2019.pdf

2. Bennet, T. (1982). Theories of the Media, Theories of Society. In M. Gurevitch, Culture, Society and the Media (pp. 30-55). London: Metheuen.

3. Berisha, I. (2007). Media-Agjensët e Komunikimit. Prishtinë: Universiteti AAB.

4. Çollaku, P. (2018). KOSOVA Treguesit për nivelin e lirisë së medieve dhe sigurisë së gazetarëve 2018. Retrieved from https://agk-ks.org/wp-content/uploads/2018/12/Treguesit-e-nivelit-te-lirisese-mediave-dhe-sigurise-se-gazetareve-Kosova2018.pdf?fbclid=IwAR2CTq4kH1ZUGtrN3LhTnGVvk4JbGSaRWb_y585Alig9_3-rDWonh7dP24o

5. Dubey, S., Biswas, P., Ghosh, R., Chatterjee, S., Dubey, M. J., Chatterjee, S., ... Lavie, C. J. (2020). Psychosocial impact of COVID-19. Diabetes \& Metabolic Syndrome: Clinical Research \& Reviews, 14(5), 779-788. doi: 10.1016/j.dsx.2020.05.035

6. Dutta, A. (2020). Fakenews Infodemic during COVID-19 Pandemic. Retrieved from https://www.researchgate.net/publication/341215853_Fakenews_Infodemic_during_COVID19_Pandemic

7. Gërguri, D. (2020, May 29). Mediat në Kosovë gjatë periudhës së COVID-19. Retrieved from https://portalb.mk/686503-media-ne-kosove-gjate-periudhes-se-covid-19/

8. Google-Trends. (2020). Covid-19. Retrieved from https://trends.google.com/trends/explore?date=2019-03-13\%202020-0902\&geo $=X K \& q=\% 2 F m \% 2 F 01$ cpyy,COVID\%2019,Virusi 
9. Goyanes, M., \& Lavin, A. (2018). The Sociology of Fake News - Factors affecting the probability of sharing political fake news online. Retrieved from https://www.lse.ac.uk/media-andcommunications/assets/documents/research/working-paper-series/WP55.pdf

10. Indeksonline. (2020). No Fake News, platformë që po lufton lajmet e rreme rreth Covidit-19, në Kosovë. Retrieved from https://indeksonline.net/no-fake-news-platforma-qe-po-lufton-lajmete-rreme-rreth-covid-19-ne-kosove1/

11. Kamberi, F. (2019). Dilemat e Tranzicionit. Prishtinë: Artini.

12. Kim, Y. (2020, March). Yuri Kim shpërndan raportin për fake news-et, shigjeton 'shpëtimtarët': Historia dhe faktet kanë rëndësi... Retrieved from https://shqiptarja.com/lajm/yuri-kimshperndan-raportin-per-fake-newset-shigjeton-shpetimtaret-historia-dhe-faktet-kane-rendesi

13. Kosova-Press. (2020). Oe nga fillimi I pandemise jane shperndare 1500 laime te rreme ne Kosove. Retrieved from https://kosovapress.com/hoxhaj-qe-nga-fillimi-i-pandemise-jane-shperndare1500-lajme-te-rreme-ne-kosove/

14. Liu, C., \& Liu, Y. (2020). Media Exposure and Anxiety during COVID-19: The Mediation Effect of Media Vicarious Traumatization. International Journal of Environmental Research and Public Health, 17(13), 4720. doi: 10.3390/ijerph17134720

15. OER Services. (n. d.). Media Effects Theories. Retrieved from https://courses.lumenlearning.com/suny-massmedia/chapter/2-2-media-effects-theories/

16. Open-Data-Kosovo. (2020). Covid-19. Retrieved from https://opendatakosovo.org/covid-19/

17. PAHO. (2020). Understanding the Infodemic and Misinformation in the Fight Against COVID-19. Retrieved from https://iris.paho.org/bitstream/handle/10665.2/52052/Factsheetinfodemic_eng.pdf?sequence $=14$

18. Sahni, H., \& Sharma, H. (2020). Role of social media during the COVID-19 pandemic: Beneficial, destructive, or reconstructive? International Journal of Academic Medicine, 6(2), 70-75.

19. Shalvee, \& Sambhav, S. (2020). Role of Mass Media and Communication During Pandemic. International Journal of Creative Research Thoughts, 8(5), 3786-3790.

20. Sinjali. (2020). Kosova s'ka se si t'i luftojë lajmet e rreme në kohën e pandemisë. Retrieved from https://sinjali.com/kosova-ska-se-si-ti-luftoje-lajmet-e-rreme-ne-kohen-e-pandemise/

21. UNESCO. (2020). Journalism, press freedom and COVID-19. Retrieved from https://en.unesco.org/sites/default/files/unesco_covid_brief_en.pdf

22. VOA. (2020, Korrik 1). Media sociale dhe teoritë e konspiracionit rreth COVID-19. Retrieved from https://www.zeriamerikes.com/a/5484889.html

23. WHO. (2020, September 13). Coronavirus disease (COVID-19) pandemic. Retrieved from https://www.who.int/emergencies/diseases/novel-coronavirus-2019 